\title{
Assessment of the Inhibitory Activity of Peptide Extracts from Hanwoo Musculus Longissimus on Angiotensin I-Converting Enzyme
}

\author{
Kuk-Hwan Seol ${ }^{1}$, Ji-Hye Song ${ }^{2}$, Thirawong Prayad, Hyoun Wook Kim ${ }^{1}$, Aera Jang ${ }^{1}$, \\ Jun-Sang Ham ${ }^{1}$, Mi-Hwa $\mathrm{Oh}^{1}$, Dong-Hun $\mathrm{Kim}^{1}$, and Mooha Lee* \\ Department of Animal and Food Biotechnology, Research Institute for Agriculture and Life Science, \\ Seoul National University, Seoul 151-921, Korea \\ ${ }^{1}$ National Institute of Animal Science, Rural Development Administration, Suwon 441-706, Korea \\ ${ }^{2} C J$ Cheiljedang Corporation Foods R\&D Nutraceuticals \& Functional Foods Center, Seoul 152-051, Korea
}

\begin{abstract}
This study was performed to measure the angiotensin I-converting enzyme (ACE) inhibitory activity of peptide extracts derived from the enzymatic proteolysis of Hanwoo Musculus longissimus (M. longissimus) during cold storage. Thermolysin $(80 \mathrm{ppm}, \mathrm{w} / \mathrm{w})$ and protease type XIII $(100 \mathrm{ppm}, \mathrm{w} / \mathrm{w})$ were injected separately or in combination for the enzymatic proteolysis of sarcoplasmic and myofibrillar proteins prior to storage at $5^{\circ} \mathrm{C}(\mathrm{T} 1)$ or at $-1^{\circ} \mathrm{C}(\mathrm{T} 2)$ in a chilling room for 9 days. Beef injected with thermolysin (E2) and thermolysin+protease type XIII (E3) showed a significantly higher degree of hydrolysis at both storage temperatures $(p<0.05)$. During the storage period, T1E2 at day 6 and T1E3 at day 9 showed the strongest ACE inhibitory activity with sarcoplasmic and myofibrillar protein proteolysates. Macromolecules greater than $10,000 \mathrm{Da}$ were removed by ultra filtration, and the filtrates were separated into fractions using gel filtration. Five and three major fractions were collected from S-T1E2-6 and M-T1E3-9 extracts, respectively, and the $4^{\text {th }}$ fraction of the S-T1E2-6 extracts showed the highest ACE inhibitory rate of $61.96 \pm 7.41 \%$.
\end{abstract}

Key words: angiotensin I-converting enzyme inhibitory activity, Hanwoo beef, thermolysin, protease type XIII

\section{Introduction}

The renin-angiotensin system is one of the most important humoral vasoconstrictor and vasodilator mechanisms involved in blood pressure regulation. In this system, angiotensinogen is first converted into a prehypertensive hormone angiotensin I (DRVYIHPE-HL), through the action of rennin, which is secreted by the kidneys. Angiotensin I is further converted to angiotensin II (DRVYIHPE), the active form of the hormone, by the action of angiotensin I-converting enzyme (ACE). The ACE catalyzes the production of the vasoconstrictor angiotensin II as well as the inactivation of the vasodilator bradykinin (RPPGFSPFR) or encephalitis (Ariyoshi, 1993; Hazato and Kase, 1986; Maruyama et al., 1985).

Inhibition of ACE is an established therapy for hypertension (Vane, 1999). Bioactive peptides are most com-

\footnotetext{
*Corresponding author: Mooha Lee, Department of Animal and Food Biotechnology, Research Institute for Agriculture and Life Science, Seoul National University, Seoul 151-921, Korea. Tel: 82-2-880-4820, Fax: 82-2-873-4804, E-mail: moohalee@ snu.ac.kr
}

monly produced by enzymatic hydrolysis of whole molecules. Peptides capable of inhibiting ACE have recently been identified in the tryptic hydrolysates of bovine $\alpha_{\mathrm{s} 2}-$ casein (Tauzin et al., 2002) and bovine, ovine and caprine K-casein macropeptides (Manso and López-Fandino, 2003). Different digestive enzyme combinations of proteinases including alcalase, chymotrypsin, pancreatin, pepsin and thermolysin as well as enzymes from bacterial and fungal sources have been used to generate bioactive peptides from various proteins (Kilara and Panyam, 2003; Korhonen and Pihlanto, 2003).

In this study, we examined the activity of peptides derived from Hanwoo M. longissimuss that are capable of inhibiting ACE under several enzymatic treatments and storage conditions.

\section{Materials and Methods}

Praparation of crude peptide extracts from Hanwoo M. longissimus

M. longissimus from Hanwoo steers aged 28-30 mon were collected from Gangwon Livestock Process Center 
(Gangwon LPC, Korea) after slaughter. A study by Jang and Lee (2005) showed that thermolysin and protease type XIII had high proteolytic activities on muscular sarcoplasmic and myofibrillar proteins, therefore, on the basis of this study, thermolysin (T7902, Sigma, USA) and protease type XIII (P2143, Sigma, USA) were injected in the beef separately or in combination. The beef was then stored at $5^{\circ} \mathrm{C}(\mathrm{T} 1)$ or $-1^{\circ} \mathrm{C}(\mathrm{T} 2)$ in chilling room for $9 \mathrm{~d}$ as shown in Table 1 . On the $3^{\text {rd }}, 6^{\text {th }}$ and $9^{\text {th }} \mathrm{d}$ of storage, the sarcoplasmic and myofibrillar proteins were extracted from the beef, and high molecular peptides of greater than $10,000 \mathrm{Da}$ were removed using an ultra-filtration system at $4^{\circ} \mathrm{C}$ with a PM-10 membrane (MWCO, 10,000 Da; Amicon Co., USA). After filtration, the filtrates were frozen in a deep freezer and then used to measure the degree of hydrolysis, and ACE inhibitory activity. Subsequently, these filtrates were further purified by gel filtration.

\section{Reagents}

ACE (from rabbit lung) and hippuryl-L-histidyl-L-leucine (HHL) were purchased from Sigma (USA) and all other chemicals used were of analytical grade (Fisher, USA).

\section{Extraction of muscular protein hydrolyzates}

Hanwoo muscular protein proteolysates were extracted by the modified method described in the study by Jang and Lee (2005). Beef samples were homogenized for 3 min in $50 \mathrm{~mL}$ of $20 \mathrm{mM}$ phosphate buffer (pH 7.4). Then homogenates were centrifuged at $4^{\circ} \mathrm{C}, 10,000 \mathrm{~g}$ for $20 \mathrm{~min}$ and filter the supernatant with a $0.45 \mu \mathrm{m}$ membrane filter, and used as sarcoplasmic protein proteolysate extracts. Myofibrillar protein proteolysate extracts were separated from the pellets by further extraction. Fifty milliliters of $20 \mathrm{mM}$ phosphate buffer (pH 7.4) and $50 \mathrm{~mL}$ of $0.1 \%$ Triton X-100 were added to the pellets. The mixtures were

Table 1. Preparation of Hanwoo M. longissimus with various enzymes and storage conditions

\begin{tabular}{cll}
\hline \hline & \multicolumn{2}{c}{ T1 } \\
\hline Con & No enzyme & No enzyme \\
E1 & 80 ppm protease type XIII & 80 ppm protease type XIII \\
E2 & 100 ppm thermolysin & 100 ppm thermolysin \\
E3 & 80 ppm protease type XIII & 80 ppm protease type XIII \\
& +100 ppm thermolysin & +100 ppm thermolysin \\
\hline
\end{tabular}

$\mathrm{T} 1,5^{\circ} \mathrm{C}$ chilling room; $\mathrm{T} 2,-1^{\circ} \mathrm{C}$ chilling room

Con, no enzyme; E1, protease type XIII $100 \mathrm{ppm} / \mathrm{meat}$ sample; E2, thermolysin $80 \mathrm{ppm} /$ meat sample; E3, protease type XIII 100 $\mathrm{ppm} /$ meat sample + thermolysin $80 \mathrm{ppm} /$ meat sample homogenized for $2 \mathrm{~min}$ and centrifuged at $4^{\circ} \mathrm{C}$ at 10,000 $\mathrm{g}$ for $20 \mathrm{~min}$, and the pellets were mixed with $50 \mathrm{~mL}$ of $0.1 \mathrm{M}$ phosphate buffer and $50 \mathrm{~mL}$ of $1.1 \mathrm{M} \mathrm{KI}$ and homogenized for $2 \mathrm{~min}$. The homogenates were then centrifuged at $4^{\circ} \mathrm{C}$ at $10,000 \mathrm{~g}$ for $20 \mathrm{~min}$. The supernatants were filtered with a $0.45-\mu \mathrm{m}$ membrane filter to separate the myofibrillar protein proteolysate extracts. Both the sarcoplasmic and myofibrillar protein proteolysate extracts were heated at $90^{\circ} \mathrm{C}$ in a water bath for 15 min to inactivate the injected enzymes.

\section{Analysis of protein content and the degree of hydro- lysis}

The total amount of protein in the extracts was measured using a protein assay kit (Sigma Co., USA) and bovine serum albumin was used as the standard. The degree of hydrolysis was analyzed by measuring the amount of nitrogen dissolved in 10\% trichloroacetic acid. Peptide extracts were mixed with an equal volume of $20 \%$ trichloroacetic acid, reacted for $30 \mathrm{~min}$ at room temperature, and then centrifuged at 1,750 $\mathrm{g}$ for $10 \mathrm{~min}$. Soluble nitrogen was measured using protein assay kit (Sigma Co., USA). The degree of hydrolysis was calculated as follows:

$$
\% \mathrm{DH}=(10 \% \mathrm{TCA} \text {-soluble protein/total protein }) \times 100
$$

\section{ACE inhibitory activity}

The ACE inhibitory activity was determined using the spectrophotometric method described by Cushman and Cheung (1971). For each assay, $100 \mu \mathrm{L}$ of HHL (12.5 $\mathrm{mM}$ in $0.05 \mathrm{M}$ sodium borate buffer) were incubated at $37^{\circ} \mathrm{C}$ for $5 \mathrm{~min}$. After incubation, $50 \mu \mathrm{L}$ of bovine peptide extracts and $150 \mu \mathrm{L}$ of ACE (peptidyldipeptide hydrolase, from rabbit lung acetone extract) were added, and the mixture incubated for $1 \mathrm{~h}$. The enzymatic reaction was stopped by adding $250 \mu \mathrm{L}$ of $0.5 \mathrm{~N} \mathrm{HCl}$. The hippuric acid formed by the action of the ACE on HHL was extracted from the acidified solution into $1 \mathrm{~mL}$ ethyl acetate by vortex mixing for $15 \mathrm{~s}$. This mixture then was centrifuged at $3,290 \mathrm{~g}$ for $10 \mathrm{~min}$ at $4^{\circ} \mathrm{C}$, and a $0.7 \mathrm{~mL}$ aliquot of each ethyl acetate layer was transferred to clean tubes and evaporated by heating at $95^{\circ} \mathrm{C}$ for $20 \mathrm{~min}$ in a water bath. The hippuric acid was dissolved again in 3 $\mathrm{mL}$ of $1 \mathrm{M} \mathrm{NaCl}$, and the amount formed was determined by measuring the absorbance at $228 \mathrm{~nm}$. The $\mathrm{IC}_{50}$ value, defined as the concentration of a peptide that inhibits $50 \%$ of the ACE activity, was determined by measuring the ACE inhibitory activity and peptide contents of each 
extract after regression analysis.

$$
\text { ACE inhibitory activity }=\left(1-\frac{\text { S }- \text { S.C. }}{B-B . C}\right) \times 100
$$

S, OD value of sample; S.C., OD value of sample control; $\mathrm{B}$, OD value of blank; B.C., OD value of blank control

\section{Separation of the active fraction inhibiting ACE}

Peptide extracts that showed high ACE inhibitory activity were selected. Molecules greater than 10,000 Da were removed by ultra filtration at $4^{\circ} \mathrm{C}$ by using a PM-10 membrane, and the ACE inhibitory activity was measured. The filtrate was refiltered using a $0.45-\mu \mathrm{m}$ Millipore membrane filter and loaded on the XK $2.6 \mathrm{~mm} \times 1 \mathrm{~m}$ (Amersham Pharmacia Biotech., UK) gel-filtration column filled with Sephadex ${ }^{\circledR}$ G-25 resins (GE Healthcare Biosciences, USA). Phosphate buffer (20 mM, pH 7.0) containing $0.05 \%(\mathrm{w} / \mathrm{v})$ sodium azide was used for the mobile phase, and the flow rate was $5.0 \mathrm{~mL} / \mathrm{min}$. Each fraction was collected and measured for ACE inhibitory activity.

\section{Statistical analysis}

All analyses were performed in triplicate. Statistical analysis was performed with the SAS program for Windows V9.1 (SAS Institute, USA). Two-way ANOVA was carried out with Duncan's multiple range test to analyze the significant differences among the treatments $(p<0.05)$.

\section{Results and Discussion}

\section{Degrees of proteolysis}

The degrees of proteolysis of the sarcoplasmic protein proteolysate (SPP) and myofibrillar protein proteolysate (MPP) extracted from samples stored at $5^{\circ} \mathrm{C}$ or $-1^{\circ} \mathrm{C}$ during the storage period are shown in Tables 2 and 3. Enzymatically proteolyzed E2 and E3 samples stored at both temperature (T1 and T2) showed significantly higher degree of proteolysis in sarcoplasmic and myofibrillar protein proteolysate extracts than others (Con and E1) $(p<0.05)$. Furthermore, the degree of proteolysis of extracts stored at $5^{\circ} \mathrm{C}$ in a chilling room was higher than those of samples stored at $-1^{\circ} \mathrm{C}$. On the $9^{\text {th }}$ day of storage, the degree of proteolysis of E3, injected with both thermolysin and protease type XIII, was high.

Although the degree of proteolysis of the Hanwoo muscular protein was lower than that previously reported by of Jang et al. (2003), who carried out proteolysis at the optimum temperature of enzyme and reported almost $70 \%$
Table 2. The degree of proteolysis of sarcoplasmic proteins with several proteases during storage

\begin{tabular}{lccc}
\hline \hline & $3 \mathrm{~d}$ & $6 \mathrm{~d}$ & $9 \mathrm{~d}$ \\
\hline T1Con & $2.98 \pm 1.44^{\mathrm{e}}$ & $2.58 \pm 1.96^{\mathrm{c}}$ & $4.58 \pm 2.27^{\mathrm{cd}}$ \\
T1E1 & $5.60 \pm 0.31^{\mathrm{cdeB}}$ & $5.27 \pm 1.27^{\mathrm{cB}}$ & $7.98 \pm 1.31^{\mathrm{cA}}$ \\
T1E2 & $9.71 \pm 0.46^{\mathrm{bcB}}$ & $16.46 \pm 5.36^{\mathrm{abA}}$ & $15.69 \pm 1.26^{\mathrm{bAB}}$ \\
T1E3 & $12.08 \pm 0.83^{\mathrm{abB}}$ & $12.87 \pm 3.65^{\mathrm{abB}}$ & $19.91 \pm 0.19^{\mathrm{aA}}$ \\
T2Con & $3.49 \pm 0.93^{\mathrm{bde}}$ & $2.79 \pm 0.39^{\mathrm{c}}$ & $3.85 \pm 1.38^{\mathrm{d}}$ \\
T2E1 & $7.90 \pm 6.32^{\mathrm{bcd}}$ & $6.10 \pm 0.93^{\mathrm{c}}$ & $5.36 \pm 0.42^{\mathrm{cd}}$ \\
T2E2 & $15.40 \pm 1.60^{\mathrm{a}}$ & $16.90 \pm 2.80^{\mathrm{a}}$ & $15.84 \pm 3.28^{\mathrm{b}}$ \\
T2E3 & $12.60 \pm 2.40^{\mathrm{abB}}$ & $11.84 \pm 0.96^{\mathrm{bB}}$ & $17.85 \pm 3.23^{\mathrm{abA}}$ \\
\hline
\end{tabular}

Values are expressed as mean $\pm \mathrm{SD}$.

$\mathrm{T} 1,5^{\circ} \mathrm{C}$ chilling room; $\mathrm{T} 2,-1^{\circ} \mathrm{C}$ chilling room.

Con, no enzyme; E1, protease type XIII $100 \mathrm{ppm} /$ meat sample; $\mathrm{E} 2$, thermolysin $80 \mathrm{ppm} / \mathrm{meat}$ sample; E3, protease type XIII 100 $\mathrm{ppm} /$ meat sample + thermolysin $80 \mathrm{ppm} /$ meat sample.

${ }^{\mathrm{a}-\mathrm{e}}$ Means in the same column with different letters are significantly different $(p<0.05)$.

${ }^{\mathrm{A}, \mathrm{B}}$ Means in the same row with different letters are significantly different $(p<0.05)$.

Table 3. The degree of proteolysis of myofibrillar proteins with several proteases during storage

\begin{tabular}{llll}
\hline \hline & $3 \mathrm{~d}$ & $6 \mathrm{~d}$ & $9 \mathrm{~d}$ \\
\hline T1Con & $2.30 \pm 0.65^{\mathrm{abA}}$ & $0.80 \pm 0.14^{\mathrm{bB}}$ & $2.96 \pm 0.33^{\mathrm{bA}}$ \\
T1E1 & $3.59 \pm 0.30^{\mathrm{ab}}$ & $2.56 \pm 1.20^{\mathrm{ab}}$ & $3.56 \pm 0.96^{\mathrm{ab}}$ \\
T1E2 & $4.22 \pm 0.91^{\mathrm{ab}}$ & $4.01 \pm 0.04^{\mathrm{a}}$ & $3.99 \pm 1.04^{\mathrm{ab}}$ \\
T1E3 & $3.89 \pm 1.80^{\mathrm{ab}}$ & $3.00 \pm 0.79^{\mathrm{ab}}$ & $4.26 \pm 0.21^{\mathrm{ab}}$ \\
T2Con & $1.14 \pm 0.13^{\mathrm{b}}$ & $3.93 \pm 2.16^{\mathrm{a}}$ & $4.77 \pm 3.13^{\mathrm{ab}}$ \\
T2E1 & $3.14 \pm 2.50^{\mathrm{ab}}$ & $2.16 \pm 0.25^{\mathrm{ab}}$ & $5.04 \pm 1.3^{\mathrm{ab}}$ \\
T2E2 & $4.75 \pm 0.95^{\mathrm{a}}$ & $4.81 \pm 1.72^{\mathrm{a}}$ & $6.59 \pm 0.02^{\mathrm{ab}}$ \\
T2E3 & $4.36 \pm 3.12^{\mathrm{a}}$ & $4.93 \pm 3.40^{\mathrm{a}}$ & $6.98 \pm 3.89^{\mathrm{a}}$ \\
\hline
\end{tabular}

Values are expressed as mean $\pm \mathrm{SD}$.

$\mathrm{T} 1,5^{\circ} \mathrm{C}$ chilling room; $\mathrm{T} 2,-1^{\circ} \mathrm{C}$ chilling room.

Con, no enzyme; E1, protease type XIII 100 ppm/meat sample; E2, thermolysin $80 \mathrm{ppm} /$ meat sample; E3, protease type XIII 100 $\mathrm{ppm} /$ meat sample + thermolysin $80 \mathrm{ppm} /$ meat sample.

${ }^{a, b}$ Means in the same column with different letters are significantly different $(p<0.05)$.

${ }_{\mathrm{A}, \mathrm{B}}$ Means in the same row with different letters are significantly different $(p<0.05)$.

after $24 \mathrm{~h}$ of reaction, it gradually increased during the storage period. These results are similar to those of Lee et al. (2005), which showed that the degree of proteolysis of every treated enzyme increases during storage. These results also correspond with those of Jang et al. (2003), which showed that the degree of proteolysis was higher in the samples injected thermolysin + protease type III, thermolysin, and protease type XIII, with the degree increasing in that order.

\section{ACE inhibitory activity}

Fig. 1 and 2 show the ACE inhibitory activities of SPP 
Table 5. The ACE inhibitory activities of gel-filtrated fractions from W-T1-E2-6 and S-T1-E3-9

\begin{tabular}{ccc}
\hline \hline Extract Fraction No. & W-T1-E2-6 & S-T1-E3-9 \\
\hline 1 & $4.15 \pm 2.79$ & $52.57 \pm 1.53$ \\
2 & $34.39 \pm 0.28$ & $28.86 \pm 3.64$ \\
3 & $44.07 \pm 3.35$ & $30.89 \pm 2.68$ \\
4 & $61.96 \pm 7.41$ & - \\
5 & $43.08 \pm 1.68$ & - \\
\hline
\end{tabular}

Values are expressed as mean $\pm \mathrm{SD}$.

$\mathrm{S}$, sarcoplasmic protein proteolysate; $\mathrm{M}$, myofibrillar protein proteolysate

$\mathrm{T} 1,5^{\circ} \mathrm{C}$ refrigerator; E2, thermolysin $80 \mathrm{ppm} / \mathrm{meat}$ sample; E3, protease type XIII $100 \mathrm{ppm} / \mathrm{meat}$ sample + thermolysin $80 \mathrm{ppm} /$ meat sample

and 3 fractions, respectively (data not shown). The ACE inhibitory activities of those fractions are shown in Table 5. The $4^{\text {th }}$ fraction at S-T1-E2-6 showed the highest ACE inhibitory activity of $61.96 \pm 7.41 \%$, and the $1^{\text {st }}$ fraction of M-T1-E3-9 showed $52.57 \pm 1.53 \%$. In this study, we did not analyze the concentration of these fractions, and separated peptides need to be identified in future studies.

The enzymatic hydrolysis of Hanwoo muscular protein may generate antihypertensive peptides. Although we did not identify the active peptides in this study, the existence of active fractions was confirmed. If significant amounts of these peptides could be generated during meat aging or manufacturing of meat products, this research would be a scientific basis for a novel industrial technology. However, further studies are needed to identify the antihypertensive peptides and other bioactive peptides derived from Hanwoo beef.

\section{References}

1. Ariyoshi, Y. (1993) Angiotensin-converting enzyme inhibitors derived from food proteins. Trends Food Sci. Technol. 4, 139-144.

2. Astawan, M., Wahyuni, M., Yasuhara, T., Yamada, K., Tadokoro, T., and Maekawa, A. (1995) Effects of angiotensin I-converting enzyme inhibitory substances derived from Indonesian dried-salted fish on blood pressure of rats. Biosci. Biotech. Bioch. 59, 425-429.

3. Cushman, D. W. and Cheung, H. S. (1971) Spectrophotometric assay and properties of the angiotensin-converting enzyme of rabbit lung. Biochem. Pharmacol. 20, 1637-1638.

4. Gomez-Ruiz, J. A., Ramos, M., and Recio, I. (2002) Angiotesin converting enzyme-inhibitory peptides in Manchego cheeses manufactured with different starters cultures. Int. Dairy J. 12, 697-706.

5. Hazato, T. and Kase R. (1986) Isolation of angiotensin-I converting enzyme inhibitor from porcine plasma. Biochem. Biophys. Res. Comm. 139, 52-55.

6. Jang A. and Lee M. (2005) Purification and identification of angiotensin converting enzyme inhibitory peptides from beef hydrolysates. Meat Sci. 69, 653-661.

7. Jang S. H., Jang A., Kim K. J., Cheon Y. H., Min J. S., Lee S. O., and Lee M. (2003). Purification and isolation for antihypertensive peptides from beef heart and spleen. J. Ani. Sci. Tech. 45, 319-326.

8. Kilara, A. and Panyam, D. (2003) Peptides from milk proteins and their properties. Crit. Rev. Food Sci. Nutr. 43, 607633.

9. Korhonen H. and Pihlanto A. (2003). Food-derived bioactive peptides - opportunities for designing future foods. Curr. Pharm. Des. 9, 1297-1308.

10. Lee K. J., Kim S. B., Ryu J. S., Shin H. S., and Lim J. W. (2005). Separation and purification of angiotensin converting enzyme inhibitory peptides derived from goat's milk whey hydrolysates. Korean J. Ani. Sci. Tech. 47, 83-90.

11. Manso, M. A. and López-Fandino, R. (2003) Angiotensin I converting enzyme-inhibitory activity of bovine; ovine; and caprine kappa-casein macropeptides and their tryptic hydrolysates. J. Food Protec. 66, 1686-1692.

12. Maruyama, S., Nakagomi, K., Tomizuka, N., and Suzuki, H. (1985) Angiotensin-I converting enzyme inhibitor derived from an enzymatic hydrolysate of casein. II. Isolation and dradykinin-potentiating activity in the uterus and ileum of rats. Agric. Biol. Chem. 49, 1405-1409.

13. Tauzin, J., Miclo, L., and Gaillard, J. (2002) Angiotensin Iconverting enzyme inhibitory peptides from tryptic hydrolysate of bovine $\alpha_{\mathrm{s} 2}$-casein. FEBS Lett. 531, 369-374.

14. Vane, J. R. (1999) The history of inhibitors of angiotensin converting enzyme. J. Physiol. Pharmacol. 50, 489-498.

(Received 2010.11.29/Revised 2011.9.6/Accepted 2011.9.16) 